\title{
Policy Making, Theories and Practices: A Study of Pakistan
}

\author{
Syed Raheem Abbas Shah \\ Assistant professor Government Postgraduate College, Bhakkar,Pkistan \\ Syed Mussawar Hussain Bukhari \\ Associate Professor Islamia university, Bhawalpur Pakistan
}

\begin{abstract}
Policy making is a purely an administrative task. No one organization can deny for this process. There can be difference in culture or traditions but policy making process is prevailed in each and every society, business and department.Being able to make policies and solve issues and problems effectively is a necessary and vital part of the job for every administrative, planner and responder. This article is designed to improve knowledge about what policy making is. It addresses meaning, concepts, process and techniques from different schools of thought. Similarly, Policy making process in differrent tenures in the hisotry of Pakistani is also discussed here.
\end{abstract}

DOI: $10.7176 /$ RHSS/9-3-06

\section{Literature Review}

N. Greston (2010), E. Anderson (2011), Keller (2008) and E. Heller (2011) discuss the theme of policy making and with highlighting its essential need in any administrative. Their focus was on the questions that why and how to design a policy with respect to the culture, traditions or the values of any particular society.

Irving Lester Janis (1989), Donna Styles (2001), Christopher Hodgkinson (1991) and Caroline Wang (2010) attached the concept of Policy Making with the leadership. They argue that there is only leadership which has an ability and skills regarding making policies.

Gebrial A. Almond (1963) was a renowned political scientist who defines the term "Policy Making" related with the government and political affairs. Similarly, there are several other scholars who are supporters of this view point, like Robert D. Pintnam (2000), Sidney Verba (1963), Warren E. Miller (1996), J. Merril Shanks (1996), John H.Aldrich (1995), James C. Humes (1995), Morris P.Fiorina (1999) and Hugh Heclo (1996). They explain this term with arguing that the only political government has a right to make policies for welfare of the people as well as for the development regarding any sector within or outside the state.

Bethany Mclean (2012), Peter Elkind (2012) and Amir Levy (1986) presented this term in the meaning of business or an organizational step. They say that every business or an organization cannot run without making its policy. Similarly, any organization which have certain goals, cannot achieve without designing parameters regarding achieving them, and these parameters are actually called Policy Making.

Firdous Arfina Osman (2012), Rubin (2009), Ernest Alexander (2012), Marc Alpart (2012), Howard Raiffa (2012), Kenneth Arrow (1951), Jonathan Baron (1987), and David E.Bell (1982) are the prominent scholars who presented process of policy making in their styles. But, their themes can be summarized in the steps of problem identifying, program designing, formulization and implementation, policy execution, and, assessment and termination.

Fulop (2011) defines the techniques of policy making with arguing that policy will be analyzed regarding its value, worth and benefits. Policy makers will look over its designing regarding its implementation with fulfilling in the long run necessities. Similarly, Vroom (1973) presents its mathematical model about policy making. He gives the way of analyzing different styles of leadership with quantitative assessment regarding policy quality, subordinate commitment and time constraints. On the other hand, Philips (2008) defines different approach of policy making regarding its designing. His approach has foundations on "pattern recognition", and on how we use historical understandings of related circumstances to influence our policies.

Ahmar (2009), Khan (2012), Mahmood (2007) and McGann (2005) present policy making process in pakistani during different regimes. Attitude of rulers towrads policy making process is highlighted in these books.

\section{Introduction}

Policy making is a pure administrative process that is a fundamental in each organization; either its governmental or private. There can be difference between the process and techniques of policy making in different organizations and societies, but each organization and society has their own culture, traditions and values, which we cannot exempt (N.Greston, 2010, P05).

\section{Policy Making: Concepts and Definitions of Policy Making}

Oxford dictionary defines "Policy" as "a course or principle of action adopted or proposed by a government, party, business or individual" (Oxford Dictionary, 2012, P.675). 
Political scientists describe the term "Policy Making" into three different meanings. This categorization is as follows:

\section{1) Policy Making is a Leadership}

Most prominent scholars like Joan Poliner Shapiro (Shapiro, 2008, P.4), Irving Lester Janis (Janis, 1989, P.244), Donna Styles (Styles, 2001, P.13), Christopher Hodgkinson (Hodgkinson, 1991, P.22) and Caroline Wang (Wang, 2010, P.34) attached "Policy Making" with the leadership. They argue that there is only leadership which has an ability and skill regarding making policies. No one other here to do this task. Due to observing long run merits and demerits, leadership can lead their followers with the help of their own designing policy.

2) Policy Making is related to Politics and Government

Gebrial A.Almond (Almond, 1963) was a renowned political scientist who defines the term "Policy Making" related with the government and political affairs. Similarly, there are several other scholars who are supporters of this view point, like Robert D.Pintnam (Putnam, 2000, PP.39-40), Sidney Verba (Verba, 1963), Warren E.Miller (Miller, 1996, P69), J.Merril Shanks (J. Merrill Shanks, 1996, P69), John H.Aldrich (Aldrich, 1995), James C.Humes (Humes, 1995), Morris P.Fiorina (Fiorina, 1999) and Hugh Heclo (Heclo, 1996). They explain this term with arguing that the only political government has a right to make policies for welfare of the people as well as for the development regarding any sector within or outside the state. Policy making has no meaning without having any political or governmental status.

3) Policy Making is a Business or an Organizational Step

Bethany Mclean (McLean, October 12, 2012), Petter Elkind (Elkind, October 12, 2012) and Amir Levy (Levy, 1986, P.220) presented this term in the meaning of business or an organizational step. They say that every business or an organization cannot run without making its policy. Correspondingly, any organization which have certain goals regarding achieving, cannot achieve without designing parameters regarding achieving them, and these parameters are actually called Policy Making.

They explain that governmental affairs are also in an organized way and government works as like an organization which is divided into several sections with allocating their own specific tasks. So, we can easily conclude that government running is also a business in an organized way, having a right of making policy. Without making policy, business or any other department cannot run (Levy, 1986, PP.222-224).

In the light of these three concepts, we can say that the term "Policy Making" has been defined as the procedure by which governments interpret their political visualization into programs and measures to deliver outcomes for preferred alteration in the factual world (E.Anderson, 2011, P.06). Policy can take a series of unusual forms, including non-involvement like regulation for case in point of licensing, or the back-up of charitable change including funding or grant aid (E.Anderson, 2011, P.48).

The transaction of policy making is not an art, but it is easier said than do well (N.Gerston, 2010, P.05). As in each and every course of action, there are several tools and techniques that can assist in doing the job more efficiently. Public policy works for a large surrounding of any location. Governments have responsibilities to and are accountable to each branch regarding public affairs. Policy making often requires a section or an organization as a whole to check an equilibrium among a broad range of challenging interests without losing vision of the preferred policy result (N.Greston, 2010, P.06).

The humanity, for which policies have to be designed, is becoming gradually more multifaceted, doubtful and changeable. General public have more information than before, have getting higher opportunities and are creating demands for services modifications regarding their personal needs (N.Greston, 2010, P.49). Key policy issues, such as societal requirements, near to the ground educational attainments and pitiable health, are associated and cannot be traced successfully by departments or organizations performing independently. Moreover, decentralization introduces a system of government which is planned to be more joined-up and approachable than in what went or passed before (N.Gerston, 2010, P.52).

Similarly, the world is gradually more interrelated and inter-reliant. National and international measures and trends can rapidly become major issues for a regional administration, for example, fast acceptance of innovative information and communications technology and a large variety of benefits necessitate being co-organizer and harnessed (N.Greston, 2010, P.71). Similarly, through these exterior pressures, Ministers look ahead to a focus on solutions that can implement across existing managerial boundaries and can helpful in bringing regarding genuine modifications. Public servants must choose this latest, dynamical and challenging atmosphere if public policy is to stay trustworthy, valuable and helpful (N.Gerston, 2010, P.77).

\section{Process of Policy Making}

Process of policy making has different styles in each and every country. It is also different in each and every department or sector of that specific country. Therefore, different scholars present process of policy making within its own inspired style. So, we have an academic result that the presentation of policy making process is only related with the subject of Political Psychology. There are several scholars who defined process of policy making in their 
own style. The most prominent scholars who presented the process of policy making are, Firdous Arfina Osman (Osman, October 12, 2012), Ernest Alexendar (R.Alexander, October 13, 2012), Marc Alpart (Alpart, October 13, 2012), Howerd Raiffa (Alpart, October 13, 2012), Kenneth Arrow (Arrow, 1951, P.11), Johathan Baron (Baron, 1987, P.23), and David E.Bell (E.Bell, 1982, P.05).

After analyzing their theories, we have finalized that there are some basic aspects which presented almost all the scholars with different names. So, we can conclude that the process of policy making is consisted off four levels from beginning to conclusion. These are as follows:

1) Problem identifying is a first step in which, there is a need of finding what an issue is. Problem identifying is a force that motivate particular department regarding debate over it regarding solving. There is identification that why and where the problem is existed in a real sense and what its reasons (E.Bell, 1982, P.11).

2) Program Designing is a second stage in policy making. Earlier than a policy can be shaped, a problem or issue must exist that is called to the concentration of the government. For example, criminal immigration has been departing on for many years, but until 1990s, people had not considered it as a serious problem that required enlarged government action (Immigration and Legal Resource Center). Furthermore, if any society likes American society tolerates a certain level of crime, although, when crime rises rapidly or dramatically, it becomes an issue or problem for policymakers regarding concentration over it. Specific measures can depart a problem on the program designing or agenda setting. In case of flooding in any town near a river, for example, lifts up the questions of whether construction of homes should be permitted to be constructed in a floodplain. The USA Patriot act passed as a new legislation on fighting against terrorism was a response to the attacks of 9/11 (Rubin, 2009, P.19).

3) The third phase is Formulization and Implementation. Policy formulization and implementation means going for solving a problem with an approach, methodology or technique. In American policy making process, Congress, the courts, the executive branch, and interest groups or lobbies may be participated. Conflicted suggestions are made often on different issues. There can be difference in opinion among president and opposition party members, for example, regarding immigration reforms. Policy formulization has tangible or quantitative conclusions. So, a bill goes to regulatory agency before Congress regarding drafts proposed rules and regulations. The process remains continue till adoption and execution. When Congress passes legislation, a policy is approved, the regulations become laws, or the Supreme Court deliver any decision on a file case (J. Merrill Shanks, 1996, P.36).

4) Policy making has a step of an Execution at forth number. The execution or imposing out of policy is usually accomplished by institutions rather than those offices that designed and adopted it. A designed structure usually presents just a wide-ranging summary of a policy. In American Political system, even Congress have mandate regarding improving water quality standards, but it is duty of Environmental Protection Agency (EPA) to give the particulars on those procedures and standards for measuring acquiescence through regulations (J. Merrill Shanks, 1996, P.38). Similarly, the Supreme Court has no system to impose its decisions, but there are other branches of government which implement its decisions. Successful execution of policy depends upon its complexity. This is in fact coordination between those departments which set the policy regarding taking outcomes and obedience (J. Merrill Shanks, 1996, P.39).

5) Assessment and Termination is on fifth number in Policy Making. Assessment means determining how sound a policy is functioning, and it is not a simple job. People use cost and benefit analysis regarding find the answer, even they are in government or not (E.Anderson, 2011, P.51).

History has told that once executed policies are not easy to terminate. If a policy is terminated, it means the policy became outdated or old fashioned, and acutely did not work. Sometimes it happens due to losing support of interest groups or public officials that considered it on their agenda in the first concern. In 1974, for example, Congress ratified a national speed limit rule of 55 miles per hour (E.Anderson, 2011, P.52). It was useful in reducing highway victims and gasoline utilization, but this law increased expenses for truck industry, and considered interruption of federal government into states regulations. So this law was redesigned in 1987 (E.Anderson, 2011, PP.52-53).

\section{Different Techniques of Policy Making}

Policy making not a cleared term, but several scholars makes it confused with public administration and public management. Firstly, we have to describe an actual facts regarding making policy. There are three or sometimes four steps which are considered necessary regarding making any policy. These steps are as follows:

1) Firstly, policy will be analyzing regarding its value, worth and benefits. Policy makers will look over its designing regarding its implementation with fulfilling in the long run necessities (Fulop, 2001, P.06)(E.Shambaugh, 2003, P05).

2) There will be judged its political aspects regarding its implementation. Policy makers will check the 
impacts of particular policy with an eye of political interests. Government always prefers its popularity regarding taking its popular steps as well as making popularity more than previous in an up-coming elections (Fulop, 2001, P.06) (E.Shambaugh, 2003, P05).

3) Policy makers will observe an economic benefits and cost regarding opting that particular policy. There is no one policy which was implemented without considering economic concerns (Fulop, 2001, P.06) (E.Shambaugh, 2003, P05).

4) Some scholars argue that there will be a fourth step of evidence measuring. Policy makers will also measure the evidences regarding need and implementation of a policy. Sometimes, some necessities are looked like an urgent need but it can be handles with other cheap or parallel procedures. So evidences are measured regarding reducing extra spending on any policy (Fulop, 2001, P.06) (E.Shambaugh, 2003, P05).

So, we can see that policy making is an important management ability. If we can be skilled regarding how to formulate sensible, well-considered policies, then we can show the way to our team for well-merited achievements (Fulop, 2001, P.06).

There are some policy making models which describes different techniques regarding policy making.

1) A Mathematical Based, Victor Vroom and Philip Yetton Model

This model was firstly presented by Victor Vroom and Philip Yetton in their book, "Leadership and Decision Making" in 1973. Soon after, in 1988, Vroom and Arthur Jago, substituted the policy tree system of the original model with an practiced system which was based on mathematics. Hence we can called this model as Vroom-jago, Vroom-yetton, or Vroom-Yetton-Jago model (Vroom).

This model concentrates on three main factors, which are policy quality, subordinate commitment and time constraints (Vroom).

Policy quality, in the sense that how essential it is to approach up with the "right" solution? Therefore, there is always a need of engaged other people in policy making process for ensure policy quality (Vroom).

Subordinate commitment, in the sense that how significant it is that our group or panel and others get involvement into the policy? When group mates or panel mates need to hug the policy, we should boost the contribution levels (Vroom).

Time constraints, in the sense that how much time we have to make the policy? The additional time we have, the comfort regarding including others and of using the policy as an occasion for team building (Vroom).

Vroom-Jago model describes three styles of leadership and their process regarding policy making. These styles and process are as follows:

\section{Autocratic Style}

In this style, we design the policy and inform others regarding it. There are two different processes for policy making in an autocratic style. Firstly, we utilize the information which we already have and design the policy, and secondly, we inquire group or panel members for particular information and once we have it, we design the policy. But the specific thing is, here we do not necessarily inform them what the information is required for (Vroom).

\section{Consultative Style}

In this style, we assemble information from the group or panel, and then design the policy. There are further two processes, in which firstly, we update group or panel members regarding what we are going to do, and we can also ask opinions individually. However, the group or panel is not brought in concert regarding debate or discussion. Secondly, we are accountable for designing policy, however, we mutually as a group or panel, discuss the situation, hear others viewpoints, and solicit proposals (Vroom).

\section{Collaborative Style}

In this style, we and our group or panel work together to find out the consensus. The group or panel designs a policy together. Mutual role, in this situation, facilitate and help the group or panel regarding finalize the policy that will be acceptable for everyone (Vroom).

\section{2) An Hypothesis Based, Kapner Tregoe Approach}

This approach is based on the hypothesis that the end objective of any policy is to design the "best possible" option. Although this is a critical feature that, the objective is not to design the perfect option, or the option that does not consisted of any fault or defect. Therefore the policy maker should allow some risks, and a significant feature of the Kepner Tregoe approach is to assist estimate and take the edge off risks regarding your policy (Decision Making Confidence).

The Kepner Tregoe approach directs us through the process of designing goals, searching and concerning substitutes, exploring the potencies and flaws of the top substitutes or alternatives, and of selecting the final "best" substitute or alternative. Its generate new ways to manage the possible problems that will harvest up as an outcome of our policy (Decision Making Confidence). 
There are four steps that highlight the procedure of Kapner Tregoe Approach and these are:

1) Situation Appraisal.

2) Problem Analysis.

3) Decision Analysis.

4) Potential Problem Analysis (Decision Making Confidence).

3) The Recognition Primed Decision Approach

The Recognition Primed Decision or RPD approach was firstly presented in the late 1980d by research psychologists Roberta Calderwood, Gary Klein, and Anne Clinton-Cirocco (Philips, 2008, P.21). Gary Klein also published this approach in his book "Sources of Power" in 1999, that how people make policies. Gary Klein is a well known researcher for founding the ground of naturalistic policy making. This is actually the study of how people design policies in insisting and high-pressure environment (Philips, 2008, P.21).

Gary Klein, Clinton-Cirocco, and Roberta Calderwood pointed out the approach after observing professionals as like emergency medical technicians or paramedics and firefighter, and nuclear technicians, who design quick and life-or-death policies in their routine life. They initiated that other policy making approach did not effectively make clear how people design good policies under pressure and confused worse conditions (Philips, 2008, P22).

This approach has foundations on "pattern recognition", and on how we use historical understandings of related circumstances to influence our policies (Philips, 2008, P22).

Whether making commonplace day-to-day policies or serious, time-sensitive policies in an urgent situation or in crisis, using these approaches will help ensure that policies are logical and rational.

\section{Policy Making in Pakistan}

As Pakistan got independence from Britain, its initial infrastructure was same as during colonial period but still, somewhat same pattern is experiencing here. To study and analyzing policy making in Pakistan, we have to divide Pakistan's history into nine period and these period are given below:

1) Strong Bureaucratic Influence on National Politics (1947-58)

2) Ayub Era (1958-69)

3) Rule of General Yahya Khan (1969-71)

4) Bhutto Era (1971-77)

5) Military Government of Zia-ul-Haq (1977-88)

6) A Decade of Two Party System (1989-1999)

7) Musharraf Era (1999-2008)

8) Third Tenure of Pakistan Peoples Party (2008-13)

9) Third Time Prime Ministership of Nawaz Sharif

\section{Strong Bureaucratic Influence on National Politics (1947-58)}

Since 1947 to 1958, bureaucracy had been very much involved in national politics. Specially after the assassination of Liaqat Ali Khan, bureaucratic involvement in politics had been increased a lot. Governor General Ghulam Muhammad and Sikandar Mirza were its major examples. Both were senior bureaucrats. On the other hand, merit was being exploited by politicians as well rather than the respecting of hierarchical structure of bureaucracy. Ayub Khan who was the chief of Army Staff at that time, had been appointed as a Defense Minister in 1954. In result, there had been a direct involvement of military into politics and now, civil bureaucracy was being hesitated to stop military interference into policy making process (Mahmood, 2007, PP.129-131)(Ahmar, 2009, PP.23-27)(McGann, 2005, PP.129-130)(Bengali, 1999, PP.05-06).

\section{Ayub Era (1958-69)}

At last, Ayub Khan took control over the government in the mid night of October $7^{\text {th }}$ and $8^{\text {th }}, 1958$ and declared first martial law in the Pakistan. He hold the office of president in October 27, 1958 after the resigning of president Sikandar Mirza. And, now he remained the President of Pakistan till the March 25, 1969. During his tenure, military bureaucracy had been ruled over the country. Every public department was headed by any of the military officer without any expertise. In this situation, economic development in Pakistan was not more than a miracle. Similarly, during introducing System of Basic Democracy, he bounded BD members to the orders of Commissioner of the divisions that were playing a role of bridge among public representatives and the president. In fact, BD members had been forced to obey any legal or illegal orders of civil-military bureaucracy for getting grants or funds for the constituencies. During this era, all the major appointments were according to the will of president rather than the merit. And, all the mainstream departments were running directly by the military. Policy making process was depending upon just one order and Tashkent declaration was its example which was considered controversial by the public and political parties of that time (McGann, 2005, PP.131-134) (Ahmar, 
2009, PP29-36).

\section{Rule of General Yahya Khan (1969-71)}

On March 25, 1069, Ayub Khan abrogated his own designed constitution and invited General Yahya Khan to take over the government. This was second martial law in the Pakistan and the tenure of Yahy Khan was from March 25, 1969 to December 20, 1971. Same patterns were adopted here as in Ayub regime and all the public departments were headed my military officers at that time. A good step that Yahya government performed was to held the first general free and fair elections. Even according to Henry Kissinger (the U.S secretary of state of foreign affairs), Yahya khan told him that there will be a coalition government in Pakistan and no one party will get simple majority. But in the results of elections, Awami League, led by Sheikh Mujeeb-ur-Rehman got overwhelming majority in National Assembly. On the other hand, Pakistan Peoples Party proved as a regional political party of Sindh and Punjab while Jamiat Ulama-e-Islam and NAP got success in NWFP and Balochistan province. This was a clear prove that bureaucracy at that time worked neutrally and did not perform nepotism. Now, civil-military bureaucracy was trying not to transfer political power to Awami League due to the pressure of Zulfaqar Ali Bhutto, the chairman of Pakistan Peoples Party. Even Yahya Khan once said that the Sheikh Mujeeb-ur-Rehman will be the next prime minister of Pakistan but in Sindh, workers of Pakistan Peoples Party started agitation against this decision. So, this conflict converted into the civil war in East Pakistan and on Decemebr 16, 1971, East Pakistan lost its status and with the help of Indian Army, Awami League became a founding party of Bangladesh. 93,000 soldiers of Pakistan army became the prisoners of war in India that was the result of wrong planning without consultation. Due to such worse defeat and massive criticism, Yahya Khan left the presidency on December 20, 1971 and transferred the powers to Zulfaqar Ali Bhutto as a first Civil Martial Law Administrator of remaining Pakistan (Ahmar, 2009, P.37) (Bengali, 1999, PP.14-17) (McGann, 2005, PP.135-136).

\section{Bhutto Era (1971-77)}

Bhutto as a civil martial law administrator or after Augest 14, 1973, as a prime minister of Pakistan adopted autocratic style of policy making even he was a democratic leader. His appointment of 3000 lawyers as judges of high court without any competitive exam is a worse example of his autocratic attitude. Similarly, his rivalry against Sardari (feudal) system in Balochistan was also an exploitation of culture and tradition of that region. That's the result, Jamiat Ulama-e-Islam (Hazarvi group) and NAP started movement against his regime that converted into massive protest against him in all over the country. During appointments, he also exploited merit system in the appointment of army chief and selected Zia-ul-Haq as a chief of army staff. And, he was the person who dismissed Bhutto's second democratic tenure and declared third martial law in Pakistan (Ahmar, 2009, PP.38-42) (Bengali, 1999, PP.20-21) (McGann, 2005, PP137-141).

But, analysts highlight his consultant attitude during making consensus on approving constitution of 1973 from the national assembly. He paved the constitutional ground in Pakistan with the agreement of all the political parties and political forces of that time. Therefore according to policy analysts, such pattern of constitutional engineering is covered his overall autocratic attitude (McGann, 2005, PP.142-143).

\section{Military Government of Zia-ul-Haq (1977-88)}

From July $5^{\text {th }}, 1977$ to August $18^{\text {th }}, 1988$, Pakistan was suffering from a rigid and conservative autocratic period that was in fact, a rule of political religiosity in Pakistan. All the law making was designed by the so-called religious scholars (mainly linked with Deobandi sect of Islam) whose prime objective was to legitimize Zia rule over Pakistan. That's the reason, $78 \%$ highly dogmatic society ${ }^{1}$ accepted Zia rule and his efforts for Islamization in Pakistan (Ahmar, 2009, PP.43-45) (Bengali, 1999, PP.22-24) (McGann, 2005, P.145).

During Pakistan's first non-party based elections of 1985, he tried to show his consultative attitude to the public and world but soon, everyone realized that Zia has been authorized for all the decisions and policy making after approval of $8^{\text {th }}$ amendment from the Parliament (called Majlis-e-Shura at that time). Actually, Zia wanted to revise patterns of Umayyad and Abbasside Caliphates where Majlis-e-Shura was an advisory council of caliph and the caliph was to authorized to make his own decision even majority of Majlis-e-Shura members oppose. Same structure had been designed of that time's parliament, but this system ended dramatically with Zia's plan crash on August $18^{\text {th }}, 1988$ and officially, ended after the revising of $8^{\text {th }}$ amendment with $13^{\text {th }}$ amendment in 1997 during Nawaz Sharif $2^{\text {nd }}$ rule (Ahmar, 2009, PP.46-47) (Bengali, 1999, PP.25-29) (McGann, 2005, PP.146-153).

\footnotetext{
${ }^{1}$ According to the research paper of Wahab Liaqat (Lecturer in Psychology at Government Postgraduate College Asghar mall, Rawalpindi City), Pakistani society is overwhelmingly highly dogmatic. Data had been collected from 403 students from different colleges, universities and madrassas of Pakistan, which showed $78 \%$ religious attitude, in which just 19 persons were $68 \%$ religious fundamentalist while 384 were $87 \%$ dogmatic according to defined scale that has been used for measuring dogmatic attitude in Iran also, during combined research of Georg Lind (now retired professor of Konstanz University, Germany) and Dr.Saeedi (Iran). So, this research indicated that Pakistani society is overall dogmatic and having highly religious attitude.
} 


\section{A Decade of Two Party System (1989-99)}

From 1989 to 1999, there was a decade of two mainstream political parties in the national politics of Pakistan. Benazir Bhutto was the daughter of Zulfaqar Ali Bhutto while Nawaz Sharif was enrolled in the politics during Zia regime as a chief minister of Punjab. Although, these were democratic tenures and parliament was playing as a role of consultative body during law making process but rivalry of both the parties against each other delivered the benefits to the presidents of that time. And, presidents had all the powers of demolishing national assembly under $8^{\text {th }}$ amendment in the constitution of 1973. Firstly, Benazir and the Nawaz government dismissed by the president Ghulam Ishaq Khan under the article 58-2(b). Benazir's second tenure was also experienced same article by the president Farooq Ahmad Khan Laghari. So, we can say that consultative patterns were rejected by the autocratic attitude in the history of policy making in Pakistan during this era (Ahmar, 2009, PP.48-59) (Bengali, 1999, PP.30-46) (McGann, 2005, PP.154-166).

In result, Nawz government was forced to remove article 58-2(b) from the constitution of 1973. So, after approval of $13^{\text {th }}$ amendment in the national assembly in 1997, semi-presidential system, designed by the military theocratic leader Zia-ul-Haq was ended and political system once again converted into pure parliamentary system according to the real constitution of 1973. Now, president once again had been bounded to get advised from Prime Minister during taking any decision of appointment or dismissing. Similarly, Nawaz Sharif tried to get advantage from the religious sentiments of the Pakistani highly dogmatic society and followed Zia's policy of Islamization on consultative patterns. He approved Shariat bill from national assembly and wanted to become Amir-ulMomineen (A highly post in the theocratic political system). But soon on the issue of limited Kargil war between Pakistan and India, the relationship between Nawaz government and Military had been worse a lot. And, in the mid night of October 11 and 12, 1999, Chief of Army Staff dismissed Nawaz government and took control over the government as a Chief Executive of Pakistan (Ahmar, 2009, PP.60-79) (Bengali, 1999, PP.47-61) (Khan, 2012, PP.122-127) (Mahmood, 2007, PP.181-183) (McGann, 2005, PP.167-169).

\section{Musharraf Era (1999-2008)}

Although Musharraf had been taken control over the politics but Rafiq Tarar was remain the president as during the initial era of Ayub Khan when Sikandar Mirza was remain president of Pakistan. But, actual powers were handling by the Chief of Army Staff. Soon, judiciary of that itme legitimized Musharraf arrival into politics and allowed him to keep the post of Chief Executive of Pakistan for remaining three years of previous democratic government of Nawaz Sharif (Ahmar, 2009, PP.81-97) (Khan, 2012, PP.128-131) (Mahmood, 2007, PP.184-185) (McGann, 2005, PP.169-173).

Before Agra visit, Musharraf wanted to get the protocol as head of state. So, he was forced President Rafiq Tarar to resign from the post of presidency. After holding the post of president, Musharraf after Agra visit, firstly designed constitutional framework called LFO 2002 and secondly, through $17^{\text {th }}$ amendment after agreement between PML-Q (ruling party of that time) and MMA (opposition party consisted upon different religious parties and groups), he had all the political powers of appointments and dismissing. Political system once again, had been converted from parliamentary to semi-presidential system. Although, there was a political party based national assembly and senate but overall political attitude was autocratic. All the consultation of parliament was depended upon the approval of president at that time. Prime Minister and other ministers had artificial status of policy makers. This system was continued till the $18^{\text {th }}$ amendment approval from the parliament in 2010 under President Zardari regime (Ahmar, 2009, PP.98-108) (Khan, 2012, PP.132-135) (Mahmood, 2007, PP.185-186).

\section{Third Tenure of Pakistan Peoples Party (2008-13)}

In elections of 2008, political parties contested in condition of promising with the public to restore original constitution of 1973. But, this tenure was in fact a tenure of national government. All the mainstream political parties of this time enjoyed this tenure even there was PML (N) or PML (Q). Although, PML (N) got separation from this coliation government after almost one year but in Punjab, it had provincial government. Similarly, MQM (Sindh based political party), ANP (Khyber Pakhtunkhwa based political party), JUI-F (religious conservative party), and PML-Q (considered right hand of military dictator Pervez Musharraf during 2002-2007 tenure) were the part of this government. But, during analyzing democratic and constitutional efforts of this government, we can say this tenure as a successful consultative tenure in the history of Pakistan (Khan, 2012, PP.136-144).

Aghaz-e-Haqooq-e-Balochistan package for the graduate students of Balochistan, NFC (National Finance Commission) award of 2010, $18^{\text {th }}$ amendment for conversion of semi-presidential system into parliamentary system once again, $19^{\text {th }}$ amendment in the constitution of 1973 for selecting the method of judges appointment, $20^{\text {th }}$ amendment in the constitution of 1973 for holding free and fair elections were the best consultative democratic examples of this tenure (Khan, 2012, P.145).

\section{Third Time Prime Ministership of Nawaz Sharif}

This time, Pakistan is running by PML (N) and Nawaz Sharif is third time prime minister here. Political system 
has a consultative attitude for policy making and its major example was the holding of all parties conference on the issue of terrorism in which, all the political parties decided to started negotiations with Taliban. A conference was held on September 09, 2013 in which, all the political parties of Pakistan got joint decision regarding starting negotiations with Talibans (Express Akhbar, September 10, 2013).

Policy making is a fundamental part of any system but its method can be different according to cultural or socio-cultural variations. Therefore, Pakistan has been experienced different styles of policy making in different tenures. Now, after $18^{\text {th }}$ amendment in the constitution of Pakistan, the prime attitude in the process of policy making in Pakistan, is consultative attitude. And, opinion of majority is being respected for adopting as a final decision. So, we can conclude that a political system can be declared as successful if there is an adoption of consultative style.

\section{References}

Aldrich, J. H. (1995). Why Parties? Chicago: University of Chicago Press.

Almond, G. A. (1963). The Civic Culture. Princeton: Princeton University Press.

Arrow, K. (1951). Social choice and individual values. London: Oxford University Press.

Baron, J. (1987). Second-order probabilities and belief functions. London: Oxford university Press.

Express Akhbar. (Septemebr 10, 2013). Islamabad: Express News Publishers

E.Anderson, J. (2011). Public Policy Making (7th ed.). Boston: Suzzane Jeans Publishers.

E.Bell, D. (1982). Regret in Decision Making under Uncertainty. London: Operations Research.

E.Heller, D. (2011). The States and Public Higher Education Policy: Affordability, Access and Accountability (Vol. Second Edication). United States of America: John Hopkins University Press.

E.Shambaugh, George. (2003). The Art of Policy Making. California: Longman.

Fiorina, M. P. (1999). Civic Engagement in American Democracy. Washington, D.C.: Brookings Institution Press. Fulop, J. (2001). Introduction to Decision Making Methods. Budapest: Laboratory of Operations Research and Decision Systems, Computer and Automation Institute, Hungarian Academy of Sciences.

Heclo, H. (1996). Presidential Power and Public Prestige: A Snarly Sort of Politics. London: Woodrow Wilson International Center for Scholars.

Hodgkinson, C. (1991). Educational Leadership: The Moral Art. Albany: State University of New York Press.

Humes, J. C. (1995). The Wit and Wisdom of Winston Churchill. New York: Harper \& Row.

J. Merrill Shanks. (1996). The New American Voter. Cambridge: Harvard University Press.

Janis, I. L. ( 1989). Crucial decisions: leadership in policymaking and crisis management. Michigan: the University of Michigan.

Keller, G. (2008). Higher Education and the New Society. Maryland: John Hopkins University Press.

Levy, A. (1986). Organizational Transformation: Approaches, Strategies, Theories. New York: Preager Publishers.

Miller, W. E. (1996). The New American Voter. Cambridge: Harvard University Press.

N.Gerston, L. (2010). Public Policy Making: Process and Principles. New York: M.E. Sharpe, Inc.

Oxford Dictionary. (2012). London, United Kingdom: Oxford University press.

Philips, G. (Ed.). (2008). Intelligent Decision Making: AN Al-Based Approach. Adelaide, Australia: Springer.

Putnam, R. D. (2000). Bowling Alone: The Collapse and Revival of American Community. New york: Simon \& Schuster.

Shapiro, J. P. (2008). Ethical Leadership And Decision Making in Education: Applying Theoretical Perspectives to Complex Delimass. New Jersy: Taylor \& Francis.

Styles, D. (2001). Class Meetings: Building Leadership, Problem Solving and Decision Making Skills in the Respectful Classroom. Ontario: PemBroke Publishers.

Verba, S. (1963). The Civic Culture. Princeton: Princeton University Press.

Vroom, V. (n.d.). Mind Tools: Essentail Skills for an Exellent Career. Retrieved October 14, 2012, from http://www.mindtools.com/pages/article/newTED_91.htm

Wang, C. (2010). Managerial Decision Making Leadership: The Essential Pocket Strategy Book. San Francisco: Wiley \& Sons.

Ahmar, M. (2009). Foreign Policy Making Process: A Case Study of Pakistan. Karachi: Department of International Relations, University of Karachi.

Bengali, K. (1999). History of Educational Policy Making and Planning in Pakistan. Islamabad: Sustainable Development Policy Institute.

Khan, I. (2012). Pakistan's Strategic Culture and Foreign Policy Making: A Study of Pakistan's Post 9/11 Afghan Policy Change. New York: Nova Science Publishers.

Mahmood, S. (2007). Good Governance Reform Agenda in Pakistan: Current Challenges. New York: Nova Sceince Publishers.

McGann, J. G. (2005). Comparative Think Tanks, Politics and Public Policy. Cornwall: MPG Books Limited. 
Elkind, P. (October 12, 2012). The Smartest Guys in the Room: The Amazing Rise and Scandalous Fall of Enron. www.cimaglobal.com/decisionmaking.

McLean, B. (October 12, 2012). The Smartest Guys in the Room: The Amazing Rise and Scandalous Fall of Enron. www.cimaglobal.com/decisionmaking.

Osman, F. A. (October 12, 2012). Public Policy Making: Theories and Their Implications. http://www.cdrb.org/journal/2002/3/3.pdf.

(n.d.). Retrieved October 13, 2012, from Decision Making Confidence: http://www.decision-makingconfidence.com/kepner-tregoe-decision-making.html

(n.d.). Retrieved October 13, 2012, from Immigration and Legal Resource Center: http://www.ilrc.org/crimes

Alpart, M. (October 13, 2012). A progress report on the training of probability assessors. http://faculty.washington.edu/jmiyamot/p466/alpertm\%20prog\%20report\%20on\%20training\%20o\%20prob $\% 20$ assessors.pdf.

R.Alexander, E. (October 13, 2012). The limits of uncertainty: A note. http://link.springer.com/article/10.1007\%2FBF00136203?LI=true.

Rubin, D. (2009). American Muliticulturalism after 9/11. Amesterdam: Amesterdam University Press. 